\title{
Current Advances in the Treatment of Basal Cell Carcinoma
}

\section{Bazal Hücreli Karsinomun Tedavisinde Güncel Gelişmeler}

\author{
Mert Çalış, Hakan Uzun \\ Hacettepe Üniversitesi Tıp Fakültesi, Plastik, Rekonstrüktif ve Estetik Cerrahi AD, Ankara, Türkiye
}

Dergiye Ulaşma Tarihi: 27.04.2016 Dergiye Kabul Tarihi: 13.05.2016 DOI:10.5505/aot.2016.69188

\section{ÖZET}

Bazal hücreli karsinom, derinin en sık görülen malign tümörü olup insidansı giderek artmaktadır. Predispozan faktörler arasında en önemlisi güneş ışınlarına maruz kalmaktır. Bununla birlikte genetik hastalıklar, organ nakilleri ve immünsupresyon da bazal hücreli karsinom gelişimini tetiklemektedir. Oldukça nadir metastaz yapmasına rağmen lokal agresif seyreder. Ana tedavi şekli cerrahi olup cerrahiye aday olmayan hastalarda radyoterapi, kriyoterapi, kemoterapi ve hedgehog yolak inhibitörleri kullanılabilir. Bu derlemede bazal hücreli karsinomun tedavisi konusunda güncel gelişmeler tartışılmıştır.

Anahtar Kelimeler: bazal hücreli karsinom, cerrahi, vismodegib

\begin{abstract}
Basal cell carcinoma is the most commonly seen malignant tumor of the skin and its incidence is gradually increasing. Sun exposure is the single most important predisposing factor. In addition, genetic disorders, organ transplantations and immunesupression may trigger the development of basal cell carcinoma. Although it metastasizes rarely, its clinical course is local aggressive. The main treatment modality is surgery. In patients who are not candidates for surgery; radiotherapy, cryotherapy, chemotherapy and hedgehog pathway modulators can be used. In this review, current advances in the treatment of basal cell carcinoma is discussed.
\end{abstract}

Keywords: basal cell carcinoma, surgery, vismodegib

\section{Giriş}

Melanom dışı deri kanserleri dünyadaki en sık kanser tipi olup her yıl 2 milyon insanda ortaya çıkmaktadır ${ }^{1}$. Bu nedenle, deri kanserleri için plastik, rekonstrüktif ve estetik cerrahi uzmanları tarafından yılda 4 milyondan fazla eksizyon yapılmaktadır. Düşük morbidite ve mortalite ile seyretmesi nedeniyle genellikle ihmal edilen bir sağlik problemi olan melanom dışı deri kanserlerinin ne yazık ki insidansı giderek artmaktadır ${ }^{2}$. Melanom dışı deri kanserlerinin dünyadaki insidansını değerlendiren sistematik bir çalışmada, dünyada en yüksek insidansın Avustralya'da olduğu ortaya konmuştur ${ }^{3}$.

Bazal hücreli karsinom (BHK) ilk olarak 1827 yilında Arthur Jacob tarafindan tariflenmiştir. BHK'nın etiyolojisinde en önemli faktör solar ultraviyole (UV) radyasyona (özellikle 290-320 nm. dalga boyundaki UVB) aralıklı olarak fazla maruz kalınmasıdır. $\mathrm{Bu}$ nedenle vücudun en fazla güneşe maruz kalan baş, boyun ve ekstremite bölgelerinde BHK'ya daha fazla rastlanır. Tüm olguların \%85'i baş boyun bölgesinde lokalizedir. UV radyasyonun tetiklediği BHK karsinogenezi, temel olarak UV radyasyonun tetiklediği DNA hasarının onarımındaki bir defekt ile ilişkilidir. Hedgehog sinyal yolaklarındaki mutasyonlar BHK gelişmesine neden olurlar ${ }^{4}$.

BHK, epidermisin bazal hücrelerinden köken alır. Tipik olarak 4. dekattan sonra ortaya çıkar, ancak özellikle Gorlin sendromu, xeroderma pigmentosum, Rasmussen sendromu gibi genadodermatozlarda istisnalar görülebilir $^{5}$. Güneş 1şınlarına maruziyet BHK gelişmesinde en önemli risk faktörü olduğu için, Fitzpatrick tip 1 ve 2 cilt yapsısına sahip açık tenli, mavi gözlü, kızıl saçlı ve çilli insanlar ve açık havada ve güneş altında çalışan insanlar daha fazla risk altındadır. Diğer risk faktörleri arasında immünsupresyon, arseniğe, kömür tozuna ve radyasyona maruz kalmak yer alır. BHK, ayrıca, yassı hücreli karsinoma gibi, kronik skar, sinüs ve yanık zemininde gelişebilir ${ }^{6}$.

Klinik olarak telanjiyektatik damarlara sahip pembe veya et renginde bir papül olarak ortaya çıkar. Giderek büyüdügünde üzerinde kurutlanma, kepeklenme, kanama ve ülserasyon görülebilir. BHK'nın histolojik 
alttipleri, nodüler, yüzeyel yayılan, pigmente, mikronodüler, infiltratif, metatipik (bazoskuamoz karsinom) ve sklerozan morfeaform tipleridir. Nodüler BHK, tüm olguların $\% 75$ 'i ile \%80'ni oluşturur. Nodüler BHK'nın da \%90'1 baş-boyun bölgesinde lokalizedir. Yüksek oranda melanin içeren bu tümörleri klinik olarak melanomdan ayırmak neredeyse imkansızdır ${ }^{7}$. Yüzeyel BHK, ikinci en sık alttip olup özellikle gövdede ve ekstremitelerde yerleşim gösterir ${ }^{8}$. Bazoskuamoz karsinom ise nadir görülen bir alttip olup morfolojik olarak BHK'ya benzemesine rağmen, BHK'ya k1yasla daha agresif seyirli ve metastaz yapmaya daha fazla eğilimlidir 9 .

BHK, yavaş büyüme ve nadir metastaz yapması ile karakterize olmasına rağmen, yetersiz sinırla eksizyon yapılması veya gecikmiş tanı konulması, daha fazla sağlıklı dokunun feda edilmesine neden olur ${ }^{10}$.

\section{BHK Tedavi Seçenekleri ve Güncel Yaklaşımlar}

BHK tedavisinde başlıca tedavi hedef leri; lezyonun total olarakuzaklaştırılması, sağlıklı dokunun korunması, fonksiyonun korunmas1, nüksün olmamas1 ve estetik olarak kabul edilebilir sonuçların elde edilmesi olarak sıralanabilir ${ }^{11}$. Klinik davranış itibariyle BHK nadiren uzak organ metastazına yol açması nedeniyle genellikle klinik ortamda değerlendirilirken ihmal edilme veya yetersiz tedavi ile iyileştirme durumları ile karşı karşıya kalınabilmektedir ${ }^{12}$.

BHK yönetiminde hastaya uygulanacak tedavinin seçiminde hasta yaşı, lezyon sayısı ve boyutları, tümörün morfolojik görünümü ve histopatolojik tipi, tümörün primer veya rekürren olması ve anatomik yerleşimi dikkate alınmalıdır. BHK yönetiminde tedavi seçenekleri temelde cerrahi ve cerrahi dış1 seçenekler olarak iki başlık altında değerlendirilebilir.

\section{Cerrahi tedavi seçenekleri;}

1. Elektrodisseksiyon ve küretaj,

2. Kriyoterapi,

3. Cerrahi eksizyon,

4. Mohs mikrografik cerrahisi, olarak siralanabilir.

Elektrodisseksiyon ve küretaj, cerrahi seçenekler arasında birinci basamak olarak tanımlanabilir. Her ne kadar deneyim sonucunda küretaj ile sağlıklı dokuya ulaşıldığı hissedilebildiği sıklıkla dile getirilse bile, bu subjektif bir tespit olup, eksizyon sonrasinda sınır güvenliği açısından patoloji tarafından değerlendirmenin mümkün olmadığ 1 da değerlendirilmeli ve lezyon genişliği dikkate alınarak seçilmiş olgularda kullanılmalıdır ${ }^{13} .2$ mm.ye kadar olan küçük ve erken tanı almış lezyonlarda \%100 tedavi sağlayan bir cerrahi seçenektir. 2-5 mm. arasındaki lezyon boyutlarında bu seçenek \%85 kadar tedavi edici olarak bulunmuştur. Daha büyük lezyonlarda ise rekürrens olasılığı dikkate alınarak elektrodisseksiyon ve küretaj seçeneği tercih edilmemelidir ${ }^{14}$.

Kriyoterapi 2 cm.ye kadar olan lezyonların tedavisinde \%97e kadar tedavi edici olarak raporlamıştır ${ }^{15,16}$. Kriyoterapi seçeneğinin uygun koşullarda uygulanması çok önemlidir. Bu tedavi seçeneği, sıvı nitrogen spreyler veya kriyoprob yoluyla uygulanmaktadir ${ }^{17}$. Sivi nitrojene daldırilan pamuktu çubuklar veya pamuk diskler yoluyla uygulanması uygun olmayıp, yüzeyel BHK lezyonlarında bile tedavi edici değildir. $\mathrm{Bu}$ tedavinin en belirgin yan etkileri uzamış ödem, hipopigmentasyon, atrofik veya hipertrofik skar gelişimi ve nöropraksi olup, en önemli dezavantaj1 uygulama sonucunda patolojik tanının konfirmasyonu ve cerrahi sinır hakkında bilgi verebilecek herhangi bir patolojik spesimen elde edilmemesidir ${ }^{6}$.

Cerrahi eksizyon BHK tedavisinde uzak ara en s1k uygulanan yöntemdir ${ }^{18,19}$. Standart eksizyon 5 yıllık rekürrens oranlarının \%2- 10 arasında değiştiği bütün primer BHK olgularda etkili tedavi seçeneğidir ${ }^{20-22}$. Genel kabul gören güvenli cerrahi sınır 3-5 mm. arasında değişmekte iken ${ }^{8} 10$ mm.den büyük, rekürren ve infiltratif BHK olgularında en az 5 mm.lik güvenli cerrahi sınır ile eksizyonun gerçekleştirilmesi planlanmalıdır. 2 cm.den büyük lezyonlarda geniş subklinik uzanım görülebileceğinden $10 \mathrm{~mm}$.ye kadar güvenli cerrahi sinır planlanabiliir ${ }^{23}$.

10 mm.den küçük lezyonlarda, gövde veya sırt gibi düşük riskli anatomik alanlarda ve reeksizyonun zor olmayacağı lezyonlarda, frozen kesitlerin değerlendirilmesi gerekmemektedir ve nihayi patoloji raporu beklenebilir. Gerekmesi halinde reeksizyon planlanmas1 hastalık seyrini olumsuz etkilemeyecektir. Ancak yüksek riskli, rekürren, morfeoform gibi agresif histolopatolojik tiplerde ve 2 
cm.den büyük lezyonlarda eksizyonu takiben intraoperatif frozen kesitlerin değerlendirilmesi gerekmektedir ${ }^{6}$.

Mohs mikrografik cerrahisi, Frederich Mohs tarafindan tanımlanmış olup, eş zamanlı olarak taze spesimenden histopatolojik değerlendirmeyi içermektedir ${ }^{24}$. Sadece vertikal planda lezyonun derinliği değil, aynı zamanda horizontal planda lezyonun tabanı da değerlendirilmektedir. Primer BHK tedavisinde basit eksizyonla kıyaslandığında maliyet 3 kat kadar fazla olarak bulunmuştur ${ }^{25}$. Primer lezyonda, 5 yıllık kür oranları \%94 ile \%99 arasında değişmektedir ${ }^{26-28}$. Mohs cerrahisinin başlıca endikasyonları $2 \mathrm{~cm}$.den büyük, rekürren, yüksek risk içeren alanlarda BHK bulunmas1, periorbital, paranazal gibi geniş sınırlarla eksizyonun zor olduğu alanlarda BHK bulunması yer almaktadır ${ }^{6}$.

BHK tedavisinde başlıca cerrahi dışı seçenekler ${ }^{29}$ :

1. Radyoterapi

2. Fotodinamik terapi

3. Farmakolojik terapi olarak sıralanabilir.

BHK radyosensitif bir tümör olup, cerrahinin yüksek riskli olduğu, yaşl1, komorbiditelerin olduğu seçilmiş olgularda tercih edilebilir ${ }^{30,31}$. Tedavide radyoterapinin tercih edildiği primer $\mathrm{BHK}$ hastalarında beş yıllık rekürrens oranları \%8-15 arasında değişmektedir ${ }^{32}$. Radyoterapi uygulanan hastalarda sik karşılaşılan komplikasyonlar uygulanan alana bağlı olarak göz kuruluğu, xerostomi, alopesi, hiperpigmentasyon ve cilt nekrozu olarak siralanabilir ${ }^{33-36}$.

Fotodinamik terapi yaklaşık olarak 20 y1ldan beri uygulanmakta olup, terapötik etkisi belirli dalgaboyunda 1 şı uygulandığında neoplastik hücreler tarafından absorbe edilmiş olan porfirinlerle reaksiyona girip, oluşan enerji ve açığa çıkan serbest oksijen radikaller vasıtasıyla hasar oluşturmasına dayanmak$\operatorname{tad}^{37}$. Bu amaçla sıklıkla 5-aminolevülinik asit kullanılmakta olup, küratif değil palyatif amaçlar için öncelikli olarak tercih edilmelidir ${ }^{38}$.

BHK tedavisinde kullanılan farmakolojik ajanların başında 5-florourasil gelmektedir. Nükleik asitlerin metilasyonunun ve timidilat sentetaz enzimlerinin inhibisyonu ile hücre proliferasyonu inhibe olmaktadır ${ }^{39}$. \%5lik 5-FU krem şeklinde sadece düşük risk taşıyan alanlardaki, küçük ve yüzeyel BHK lezyonlarına uygulanmaktadır. Günde iki defa ve en az 6 ay boyunca uygulanmaktadır. Çok küçük lezyonlarda tedavi edici olabildiği doğru hasta seçimi çok önemli olup, yakın takip gerekmektedir. BHK tedavisindekullanılabilen bir başka farmakolojik ajan immün sistem üzerinde sitokin salınımını uyararak interferonlar üzerinde etkisi ortaya çıkartan imiquimod olup, yine \%5lik krem formunda uygulanmaktadır. Amerikan İlaç ve Gıda Dairesi'nin de onayını almış olan bu ilaç yüz dışındaki alanlarda yüzeyel lezyonlara uygulanabilmektedir ${ }^{40}$. Yine yüzeyel, küçük lezyonlarda uygulanabilen bir başka farmakolojik ajan reseptör selektif bir retinoid olan tazarotendir. Cilt kanseri hücrelerinde apoptoz indüklenerek ve hücre çoğalması baskılanarak etkili olmaktadır. Cilt irritasyonu yaratması ve uzun kullanım süreleri gerektirmesi ilacın kullanımında en önemli dezavantajlardır ${ }^{41}$.

Mevcut cerrahi dișı seçeneklerin kullanımı sadece yüzeyel ve küçük lezyonlarla kısıtlı iken, güncel geliştirilen ve hedgehog sinyal yolağı üzerinde etkisini gösteren vismodegib, metastatik ve lokal ileri evre BHK hastaların tedavisinde yeni bir tedavi seçeneği olarak gözükmektedir.

\section{Hedgehog Sinyal Yolağı}

PTCH1 geninin mutasyonları ilk olarak Gorlin sendromunda, daha sonra da sporadik BHK'da tanımlanmıştır ${ }^{42,43}$. Sonic hedgehog (SHH) yolağının bir üyesi olan PTCH1 geni, smoothened (SMO) ad1 verilenbirtrans- membranproteine bağlanan ve onu inaktive eden başka bir transmembran proteini kodlar. SHH yolağı, hücresel proliferasyonda görev alması nedeniyle embriyonik hayatta kritik bir öneme sahiptir ${ }^{44}$. İlginç olarak, Gorlin sendromunda görülen BHK'da ve diğer tümörlerde PTCH1 geninde mutasyonlar saptanmış, aynı zamanda sporadk BHK olgularında da PTCH1 geni mutasyonu ve SMO mutasyonları tespit edilmiştir ${ }^{45}$. UVilişkili PTCH1 mutasyonları xeroderma pigmentosumlu hastalarda da görülür ${ }^{46}$.

\section{Vismodegib}

Vismodegib (GDC-0449), bir

SMOinhibitörü-dür. Aynı gen yolağına sahip medulloblastoma allogreftlerinde etkinliği gösterilmiştir ${ }^{47}$. Faz-1 çalışması 68 ileri evre kanserli hastada ve 33 ileri evre BHK (15 lokal ileri ve 18 metastatik) hastasinda 
tamamlanmıştır. Yaygın görülen yan etkileri arasinda kas spazmları, tat almada bozukluk, yorgunluk, saç dökülmesi ve bulantı yer almaktadır. Metastatik BHK hastalarının yanıt oranı \%50, lokal ileri BHK hastalarının yanıt oran1 \%60 olarak bulunmuştur ${ }^{48,49}$. Faz-2 çalışmasına tüm BHK hastalarına günlük 150 mg Vismodegib uygulanmıştır. Çalışmaya dahil edilen 104 hastanın 96'sindan (63 lokal agresif, 33 metastatik) sonuçlar elde edilmiş ve metastatik BHK için \%30, lokal ileri BHK için $\% 43$ yanıt alınmıştır. Lokal ileri BHK grubunda, 13 hastada komplet yanıt (patolojik incelemede BHK'nın gösterilememesi) alınmıştır ${ }^{50}$. Bu fazda en sik görülen yan etkiler, kas spazmları, alopesi, tat bozuklukları, kilo kayb1, yorgunluk, bulant1, anoreksi ve ishal olmuştur. Alopesi ve tat bozukluklarının sebebi olarak k1l foliküllerinde ve tat tomurcuklarında SMO inhibitörü ile inaktive edilen Hedgehog yolağının bulunması gösterilmiştir. Bu faz-2 çalışması ile 2012 y1lında lokal ileri, unrezektabl ve metastatik BHK için Amerikan Gıda ve İlaç Dairesi (FDA) tarafından onaylanmıştır50.

Şu anda vismodegibin neoadjuvan veya adjuvan tedavide kullanılmasinı destekleyen randomize kontrollü bir çalışma yoktur. Vismodegibin operabl (rezektabl) BHK'da Mohs mikrografik cerrahi sonrasinda kullanımını araştıran bir Faz-II çalışması mevcuttur ancak henüz sonuçları bilinmemektedir (NCT01201915). Yakın dönemde 11 primer BHK hastasinda yapilan küçük bir çalışmada cerrahi defektin \%27 oranında azaldığı gösterilmiştir ${ }^{51}$.

Vismodegib tedavisi alan hastalarda yassı hücreli karsinom geliştiğine dair yayınlar mevcuttur. Henüz kesin bir kanıt olmamakla birlikte hedgehog sinyalinin azalması YHK karsinogenezisini artırıyor olabilirr ${ }^{52}$.

\section{Sonuç}

BHK tedavisinde cerrahi ve cerrahi dış1 birçok tedavi seçeneği olmasına rağmen tümör rekürrens oranları ve maliyet-kazanç oranları da dikkate alındığında en sik başvurulan seçenek olan cerrahi eksizyon, tedavide ilk basamak olarak gözükmektedir. Cerrahi dişı mevcut diğer seçenekler küçük, yüzeyel lezyonlarda etkili olmasına rağmen güncel tedavi seçeneklerinden olan hedgehog sinyal yolak inhibitörleri cerrahi eksizyonun mümkün olmadığı, ileri rekürren veya metastatik BHK olgularında sistemik tedavi olanağı sağlayarak gelecek vaadetmektedir. Cerrahi eksizyonun zor veya mümkün olmadığı rekürren, metastatik veya rekürrens yüksek riskli olgularda hedgehog sinyal yolak inhibitörlerinin tedavide yeri olabileceği akılda tutulmalıdır.

\section{Çıkar Çatışması: Yok}

\section{Kaynaklar}

1. Jemal A, Saraiya M, Patel P, et al. Recent trends in cutaneous melanoma incidence and death rates in the United States, 1992-2006. J Am Acad Dermatol 2011;65:S17-25 e1-3

2. Geller AC, Annas GD. Epidemiology of melanoma and nonmelanoma skin cancer. Semin Oncol Nurs 2003;19:2-11

3. Lomas A, Leonardi-Bee J, Bath-Hextall F. A systematic review of worldwide incidence of nonmelanoma skin cancer. $\mathrm{Br} \mathrm{J}$ Dermatol 2012;166:1069-80

4. Goppner D, Leverkus M. Basal cell carcinoma: from the molecular understanding of the pathogenesis to targeted therapy of progressive disease. J Skin Cancer 2011;2011:650258

5. Goldberg LH. Basal cell carcinoma. Lancet 1996;347:663-7

6. Netscher DT, Leong M, Orengo I, Yang D, Berg C, Krishnan B. Cutaneous malignancies: melanoma and nonmelanoma types. Plast Reconstr Surg 2011;127:37e-56e

7. Scrivener Y, Grosshans E, Cribier B. Variations of basal cell carcinomas according to gender, age, location and histopathological subtype. Br J Dermatol 2002;147:41-7

8. Gulleth Y, Goldberg N, Silverman RP, Gastman BR. What is the best surgical margin for a Basal cell carcinoma: a meta-analysis of the literature. Plast Reconstr Surg 2010;126:1222-31

9. Shanoff LB, Spira M, Hardy SB. Basal cell carcinoma: a statistical approach to rational management. Plast Reconstr Surg 1967;39:619-24

10. Kimyai-Asadi A, Alam M, Goldberg LH, Peterson SR, Silapunt S, Jih MH. Efficacy of narrow-margin excision of well-demarcated primary facial basal cell carcinomas. J Am Acad Dermatol 2005;53:464-8

11. Goldberg L, Stal S, Spira M. Recognition and treatment of recurrent basal cell carcinoma. Ann Plast Surg 1983;11:313-8

12. von Domarus H, Stevens PJ. Metastatic basal cell carcinoma. Report of five cases and review of 170 cases in the literature. J Am Acad Dermatol 1984; 10:1043-60

13. Dubin N, Kopf AW. Multivariate risk score for recurrence of cutaneous basal cell carcinomas. Arch Dermatol 1983;119:373-7

14. Suhge d'Aubermont PC, Bennett RG. Failure of curettage and electrodesiccation for removal of basal cell carcinoma. Arch Dermatol 1984;120:1456-60 
15. Zacarian SA. Cryosurgery in the management of cutaneous disorders and malignant tumors of the skin. Compr Ther 1994;20:379-401

16. Zacarian SA. Cryosurgery of cutaneous carcinomas. An 18-year study of 3,022 patients with 4,228 carcinomas. J Am Acad Dermatol 1983;9:947-56

17. Knox JM, Freeman RG, Duncan WC, Heaton CL. Treatment of skin cancer. South Med J 1967;60:2416

18. Vallejo-Torres L, Morris S, Kinge JM, Poirier V, Verne J. Measuring current and future cost of skin cancer in England. J Public Health (Oxf) 2014;36:140-8

19. Flohil SC, Proby CM, Forrest AD, et al. Basal cell carcinomas without histological confirmation and their treatment: an audit in four European regions. $\mathrm{Br}$ J Dermatol 2012;167 Suppl 2:22-8

20. Chren MM, Linos E, Torres JS, Stuart SE, Parvataneni R, Boscardin WJ. Tumor recurrence 5 years after treatment of cutaneous basal cell carcinoma and squamous cell carcinoma. J Invest Dermatol 2013;133:1188-96

21. Hausauer AK, Maurer T, Leslie KS, Parvataneni R, Stuart SE, Chren MM. Recurrence after treatment of cutaneous basal cell and squamous cell carcinomas in patients infected with human immunodeficiency virus. JAMA Dermatol 2013;149:239-41

22. Chren MM, Torres JS, Stuart SE, Bertenthal D, Labrador RJ, Boscardin WJ. Recurrence after treatment of nonmelanoma skin cancer: a prospective cohort study. Arch Dermatol 2011;147:540-6

23. Hoorens I, Vossaert K, Ongenae K, Brochez L. Is early detection of basal cell carcinoma worthwhile? Systematic review based on the WHO criteria for screening. Br J Dermatol 2016

24. Flohil SC, van Dorst AM, Nijsten T, Martino Neumann HA, Munte K. Mohs micrographic surgery for basal cell carcinomas: appropriateness of 'Rotterdam' criteria and predictive factors for three or more stages. J Eur Acad Dermatol Venereol 2013;27:1228-35

25. Essers BA, Dirksen CD, Nieman FH, et al. Costeffectiveness of Mohs Micrographic Surgery vs Surgical Excision for Basal Cell Carcinoma of the Face. Arch Dermatol 2006;142:187-94

26. Do D. Mohs micrographic surgery for Basal cell carcinoma of the face. Arch Dermatol 2009; $145: 1428-30$

27. Mosterd K, Krekels GA, Nieman FH, et al. Surgical excision versus Mohs' micrographic surgery for primary and recurrent basal-cell carcinoma of the face: a prospective randomised controlled trial with 5-years' follow-up. Lancet Oncol 2008;9:1149-56

28. Smeets NW, Kuijpers DI, Nelemans P, et al. Mohs' micrographic surgery for treatment of basal cell carcinoma of the face--results of a retrospective study and review of the literature. $\mathrm{Br} \mathrm{J}$ Dermatol 2004:151:141-7

29. Limmer BL, Clark D. Nonsurgical management of primary skin malignancies. Otolaryngol Clin North Am 1993;26:167-83

30. Knox JM. Treatment of skin cancer. J Am Acad Dermatol 1985;12:589

31. Handa Y, Miwa S, Yamada M, Ono H, Suzuki T, Tomita Y. Multiple pigmented basal cell carcinomas arising in the normal-appearing skin after radiotherapy for carcinoma of the cervix. Dermatol Surg 2003;29:1233-5

32. Zagrodnik B, Kempf W, Seifert B, et al. Superficial radiotherapy for patients with basal cell carcinoma: recurrence rates, histologic subtypes, and expression of p53 and Bcl-2. Cancer 2003;98:2708-14

33. Avril MF, Auperin A, Margulis A, et al. Basal cell carcinoma of the face: surgery or radiotherapy? Results of a randomized study. $\mathrm{Br} \mathrm{J}$ Cancer 1997;76:100-6

34. Smith SP, Grande DJ. Basal cell carcinoma recurring after radiotherapy: a unique, difficult treatment subclass of recurrent basal cell carcinoma. J Dermatol Surg Oncol 1991;17:26-30

35. Orton CI. The treatment of basal cell carcinoma by radiotherapy. Clin Oncol 1978;4:317-22

36. Cobb GM, Thompson GA, Allt WE. Treatment of Basal Cell Carcinoma of the Eyelids by Radiotherapy. Can Med Assoc J 1964;91:743-8

37. Morton CA, Brown SB, Collins S, et al. Guidelines for topical photodynamic therapy: report of a workshop of the British Photodermatology Group. Br J Dermatol 2002;146:552-67

38. Puccioni M, Santoro N, Giansanti F, et al. Photodynamic therapy using methyl aminolevulinate acid in eyelid basal cell carcinoma: a 5-year followup study. Ophthal Plast Reconstr Surg 2009;25:115-8

39. Miller BH, Shavin JS, Cognetta A, et al. Nonsurgical treatment of basal cell carcinomas with intralesional 5-fluorouracil/epinephrine injectable gel. J Am Acad Dermatol 1997;36:72-7

40. Marks R, Gebauer K, Shumack S, et al. Imiquimod $5 \%$ cream in the treatment of superficial basal cell carcinoma: results of a multicenter 6-week doseresponse trial. J Am Acad Dermatol 2001;44:807-13

41. Bianchi L, Orlandi A, Campione E, et al. Topical treatment of basal cell carcinoma with tazarotene: a clinicopathological study on a large series of cases. Br J Dermatol 2004;151:148-56

42. Hahn H, Wicking C, Zaphiropoulous PG, et al. Mutations of the human homolog of Drosophila patched in the nevoid basal cell carcinoma syndrome. Cell 1996;85:841-851

43. Johnson RL, Rothman AL, Xie J, et al. Human homolog of patched, a candidate gene for the basal cell nevus syndrome. Science 1996;272: 1668-1671

44. Lin TL, Matsui W. Hedgehog pathway as a drug target: smoothened inhibitors in development. OncoTargets Ther 2012;5: 47-58

45. Xie J, Murone M, Luoh SM, et al. Activating smoothened mutations in sporadic basal-cell carcinoma. Nature 1998;391(6662):90-92

46. Daya-Grosjean L, Sarasin A. UV-specific mutations of the human patched gene in basal cell carcinomas from normal individuals and xeroderma pigmentosum patients. Mutation Res 2000;450:193-199

47. Robarge KD, Brunton SA, Castanedo GM, et al. GDC-0449-a potent inhibitor of the hedgehog pathway. Bioorg Med Chem Lett 2009;19: 55765581

48. Von Hoff DD, LoRusso PM, Rudin CM, et al. Inhibition of the hedgehog pathway in advanced basal-cell carcinoma. N Engl J Med 2009;361:11641172

49. LoRusso PM, Rudin CM, Reddy JC, et al. Phase I trial of hedgehog pathway inhibitor vismodegib 
(GDC-0449) in patients with refrac- tory, locally advanced or metastatic solid tumors. Clin Cancer Res 2011;17:2502-2511

50. Sekulic A, Migden MR, Basset-Seguin N, et al. Long-term safety and efficacy of vismodegib in patients with advanced basal cell carcinoma: final update (30-month) of the pivotal ERIVANCE BCC study [abstract]. J Clin Oncol 2014;32:5s(Suppl; abstr 9013)
51. Ally MS, Aasi S, Wysong A, et al. An investigatorinitiated open-label clinical trial of vismodegib as a neoadjuvant to surgery for high-risk basal cell carcinoma. J Am Acad Dermatol 2014;71(5):904911. e1. Epub June 11, 2014

52.Wakabayashi Y, Mao JH, Brown K, Girardi M, Balmain A. Promotion of Hras-induced squamous carcinomas by a polymorphic variant of the patched gene in FVB mice. Nature 2007;445(7129):761-765. 